\title{
TAFSIRAYAT-AYAT TENTANG KONSUMSI (Aplikasi Tafsir Ekonomi al-Qur'an)
}

\author{
Oleh: Lukman Fauront
}

\section{Abstract}

This essay tries to develop economic studies from the point of view of Quranic economic tafsir. As a methodology, tafsir plays significant role in order to develop Islamic economic discipline. This model of economic tafsir derived from the thematic Quranic interpretation is developed through four phases including; classification of Quranic verses pertinent to economic affairs, understanding them based on chronology, micro and macro context, and socio-economic contextualization. To sum up, this paper reveals that the consumption behavior in the Quran is ruled barmoniously, gradually and systematically in order to propose the new model of consumption for the Muslim community through eight axiomatic Islamic consumption behavior.

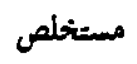
هذه المقالة تحاول تطوير الدراسة الاقتصادية من وبهة نظر التفسير الاقتصادي القرآني. اعتبارا من أن التفسير

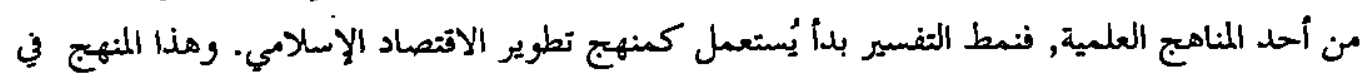

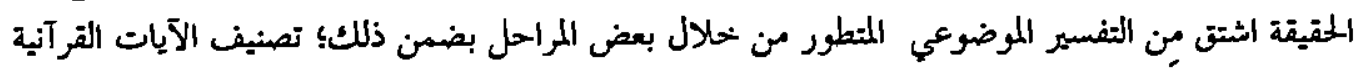

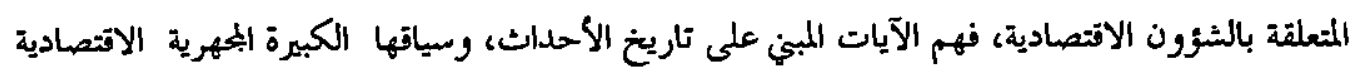

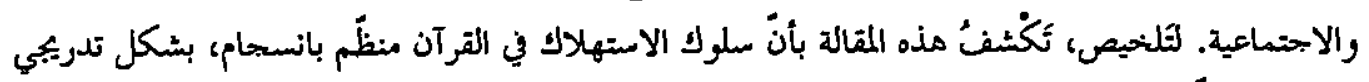

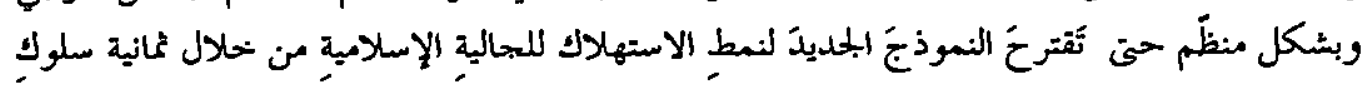
الاستهلاك الإسلامي البديهي.

Keyword: economic tafsir al-Qur'an, adabi al-Ijtima'i wal iqtishadiyyah, consumer behaviour, axiomatic Islamic consumption behavior

\section{A. Pendahuluan}

Al-Qur'an merupakan sumber penggalian dan pengembangan ajatan Islam dalam berbagai dimensi kehidupan manusia. Untuk melakukan penggalian dan

${ }^{1}$ Dosen STEI Yogyakarta, peserta program doctor ekonomi Islam UIN Sunan Kalijaga. Email: elfauroni@yahoo.co.id. 
pengembangan pemahaman terhadap al-Qur'an dipersyaratkan suatu kualifikasi kemampuan tertentu guna menghasilkan pemahaman yang baik mengenai berbagai perilaku kehidupan manusia, termasuk dalam bidang ekonomi.

Perilaku konsumsi dalam kajian ekonomi Islam mempunyai karakteristik perbedaan standar perilaku yang khas. Secara ideal setiap perilaku muslim, termasuk dalam perilaku konsumsi harus mempunyai pijakan dari sumber ajaran al-Qur'an dan Hadis. Karena itu pengembangan ilmu ekonomi Islam harus digali dan dikembangkan dari kedua sumber ajaran tersebut.

Pengembangan ilmu ekonomi Qur'ani pada dasarnya mempunyai peluang yang sama dengan pengembangan ilmu-ilmu lain dalam tradisi keilmuan Islam. Sayang, sebagai suatu disiplin ilmu, ilmu ekonomi Qur'ani belum berkembang pesat. Padahal kebutuhan terhadap ilmu ini dirasakan sudah mendesak, sehubungan kegagalan ilmu ekonomi modern dalam merealisasikan pembangunan kesejahteraan dan kemaslahatan masyarakat.

Khazanah fiqh muamalat mempunyai kontribusi yang tak terkira pada bidangnya, hanya saja karena lahir dan berkembang dalam ranah hukum Islam (fiqh), fiqh muamalat ${ }^{2}$ seakan terpisah dari ranah ilmu ekonomi. Berdasar hal itu, penggalian ilmu ekonomi Islam yang dikembangkan dari sumber al-Qur'an tanpa meninggalkan khazanah keilmuan seperti fiqh muamalat, menjadi tugas agenda para pegiat ekonomi Islam.

Tulisan ini akan menafsirkan ayat-ayat tentang konsumsi dengan pendekatan tafsir ekonomi al-Qur'an. Pilihan atas masalah konsumsi didasarkan pada kebutuhan terhadap suatu perilaku konsumsi umat yang baik. Konsumsi termasuk masalah problematis, namun strategis dalam menentukan keseimbangan ekonomi. Jika pola konsumsi masyarakat tinggi maka dapat menimbulkan penyakit ekonomi seperti inflasi, instabilitas hatga, praktik penimbunan, ketiadaan barang-barang kebutuhan pokok dan ketidakseimbangan pasar. Penyakit tahunan ekonomi seperti angka inflasi yang tinggi pada setiap bulan puasa, hari Raya Idul Fitri, apalagi bila berdekatan dengan Natal dan Tahun Baru di antaranya disebabkan oleh tingginya pola konsumsi masyarakat.

${ }^{2}$ Dalam kontek perkembangan ilmu ekonomi Islam, menurut Munrokhim Misanan Figh muamalat dianggap sebagai generasi pertama. Generasi kedua, ekonomi Islam normatif yaitu gabungan antara ajaran Islam dengan figh Muamalat. Genetasi Ketiga, implementasi ekonomi Islam dalam praktek ekonomi yang terlihat dengan perkembangan lembaga-lembaga keuangan syariah. Dan generasi keempat, adalah formulasi teoritisasi ilmu ekonomi Islam. Pengkategotian ini, pada satu sisi yaitu aspek realitas ada benarnya, namun belum mempunyai pijakan data historis yang konkrit. 


\section{B. Metodologi}

Sebagai sebuah metodologi, tafsir ekonomi al-Qur'an mempunyai peluang yang baik bagi pengembangan ilmu ekonomi Islam. Model tafsir ini dimodifikasi dari metode tafsir tematik dengan tahapan kerja sebagai berikut: perlama, menginventarisasi ayat-ayat yang terkait dengan permasalahan ekonomi yang akan dibahas, baik berdasar pada kata kunci maupun pada kandungan ayat. Kedua, mengurutkan ayat-ayat tersebut berdasar urutan turunnya surat yang didukung oleh asbabun nuzul baik secara mikro maupun makro. Ketiga, menafsirkan ayat-ayat dengan corak adabi al-ijtimâ'i wal-iqtisbâdiyyah'. Keempat, melakukan konstektualisasi dalam realitas perekonomian.

\section{Konsumsi}

Konsumsi berasal dari bahasa Belanda consumptie yang berarti suatu kegiatan yang bertujuan mengurangi atau menghabiskan daya guna suatu benda, barang maupun jasa dalam rangka memenuhi kebutuhan. Konsumen adalah individu atau kelompok pengguna barang atau jasa. Jika pembelian ditujukan untuk dijual, maka ia disebut distributor.

Keberadaan tingkat pendapatan seseorang cukup menentukan terhadap pola konsumsinya. Pendapatan yang tinggi memungkinkan tingginya konsumsi. Namun, hubungan antara pendapatan dan konsumsi tidak selalu sama untuk semua barang dan jasa. ${ }^{4}$ Konsumsi dapat berubah-ubah sesuai kondisi pendapatan. Perubahan pendapatan konsumen pada umumnya berakibat pada perubahan jumlah barang yang diminta, terutama pada jenis barang "normal" atau "superior". Sebaliknya pendapatan konsumen yang berkurang, mendorong berkurangnya konsumsi kedua jenis barang tersebut.

Perubahan kuantitas barang yang diminta dipengaruhi oleh dua hal yaitu efek substitusi (substitution effect) dan efek pendapatan (income effect). Efek substitusi adalah perubahan barang yang diminta ketika terjadi perubahan harga, sementara pendapat-

${ }^{3}$ Memilih landasan metode adabi al-ijtimâti yang dikembangkan ke aras ekonomi didasatkan pada kesimpulan bahwa atas ekonomi merupakan bidang sosial. Sebetulnya dapat juga dilakukan langsung dengan metode adabi al-igtishadiyah, hanya saja metode terakhir sepengetahuan penulis belum ada kitab tafsir yang masuk dalam kategori ini. Dengan demikian, metode adabi al-ijtimâ $i$ wal iqtishâdijab berpijak pada tafsir-tafsir yang digolongkan pada tafsir bercorak adabi al-ijtima'i.

${ }^{4}$ Lincolin Arsyad, Ekonomi Manajerial, Ekonomi Mikro Terapan sntuk Manajemen Bisnis, (Yogyakarta: BPFE, 1998), hal. 85. 
an disesuaikan agar tingkat kepuasan konsumen tetap. Efek substitusi bernilai negatif, karena perubahan harga dan kuantitas selalu berhubungan terbalik. Jika harga suatu barang tinggi, maka konsumsinya akan berkurang. Sebaliknya jika harga rendah maka konsumsinya akan bertambah. ${ }^{5}$

Sebaliknya, kuantitas suatu barang yang dikonsumsi berubah dapat ketika terjadi perubahan pendapatan riil meskipun harga tidak berubah. Perubahan pendapatan riil selalu berlawanan arah dengan perubahan harga. Kenaikan hatga akan menurunkan pendapatan riil, penurunan hatga menaikkan pendapatan riil. Efek pendapatan ini dapat berdampak positif atau negatif.

Seorang konsumen umumnya dihadapkan kepada sejumlah barang yang harus dia pilih untuk dikonsumsi. Dia harus memilih karena pendapatan atau penghasilan yang dimiliki untuk memperoleh barang jasa yang tersebar terbatas adanya. Dalam teori konsumsi dipelajari bagaimana seorang konsumen mengambil keputusan memilih barang dan jasa serta jumlahnya untuk dikonsumsi.

Menurut Umar Burhan nilai guna suatu barang adalah yang dapat memberikan kepuasan disebut utility. Tentu saja nilai guna barang yang satu tidak selalu sama dengan nilai guna barang yang lain. Nilai guna juga bisa berbeda karena waktu atau tempat yang berbeda.

Dari penjelasan di atas dapat disimpulkan bahwa seorang konsumen harus memilih barang yang lebih berguna dan bermanfaat bagi dirinya, tidak memilih barang sembarangan, dengan nilai guna yang lebih bermanfaat dan bisa memberikan kepuasan. Nilai guna yang baik adalah nilai guna yang memberikan kepuasan dan bermanfaat.

Bagaimanakah ekonomi Islam menyikapi permasalahan tentang perilaku konsumen? Terdapat empat prinsip dalam sistem ekonomi Islam dalam perilaku ekonomi, termasuk konsumsi di dalamnya:

1. Hidup hemat dan tidak bermewah-mewah (abstain from wasteful and luxurius living); bahwa tindakan ekonomi diperuntukan untuk pemenuhan kebutuhan hidup (needs) bukan pemuasan keinginan (wants).

2. Implementasi zakat yang diwajibkan dan infak, shadaqah, wakaf, hadiah, yang bersifat sukarela, mempunyai pengaruh terhadap perilaku konsumen muslim.

${ }^{5}$ Umar Buthan, Konsep Dasar Teori Ekonomi Mikro, (Surabaya: BPFE UNIBRAW, 2006), hal. 66. 
3. Menjalankan usaha-usaha yang halal (permissible conduct), jauh dari riba, maisir dan gharar; meliputi bahan baku, proses produksi out put produksi hingga proses distribusi dan konsumsi harus dalam kerangka halal.

Dari prinsip-prinsip demikian, terlihat bahwa model perilaku muslim dalam menyikapi harta benda dan jasa bukanlah merupakan tujuan. Kesemuanya merupakan media untuk akumulasi kebaikan dan pahala demi tercapainya falab (kebahagiaan dunia dan akhirat). Harta merupakan pokok kehidupan karenanya harus dijaga dan dikembangkan melalui pola-pola produktif (QS. an-Nisa: 5). Harta benda merupakan karunia Allah yang diberikan kepada manusia sesuai dengan usaha yang dilakukannya (QS. an-Nisa: 32).

Islam memandang segala yang ada di muka bumi dan seisinya adalah milik Allah SWT, yang diciptakan untuk manusia. Manusia boleh memilikinya secara sempurna namun tetap dalam Kekuasaan Allah SWT. Karena itu, kepemilikan manusia atas harta benda merupakan amanah. Dengan nilai amanah itulah manusia dituntut untuk menyikapi harta benda untuk mendapatkannya dengan cara yang benar, proses yang benar dan pengelolaan dan pengembangan yang benar pula.

Sebaliknya dalam perspektif konvensional, harta merupakan asset yang menjadi hak pribadi. Sepanjang kepemilikan harta tidak melanggar hukum atau undangundang, maka harta menjadi hak penuh si pemiliknya. Dengan demikian perbedaan Islam dan konvensional tentang harta, tetletak pada perbedaan cara pandang. Islam cenderung melihat harta berdasarkan flow concept sedangkan konvensional memandangnya berdasarkan stock concept.

Adiwarman membahas harta, dimasukan dalam pembahasan uang dan kapital. Menurut beliau uang dalam Islam adalah public goods yang bersifat flow concept sedangkan kapital merupakan private goods yang bersifat stock concept. Sementara itu menurut konvensional uang dan kapital merupakan private goods.

Namun pada tingkatan praktis, prilaku ekonomi (economic bebavior) sangat ditentukan oleh tingkat keyakinan atau keimanan seseorang atau sekelompok orang yang kemudian membentuk kecenderungan prilaku konsumsi dan produksi di pasar. Dengan demikian dapat disimpulkan tiga karakteristik perilaku ekonomi dengan menggunakan tingkat keimanan sebagai asumsi.

'Lihat Adiwarman Azwar Karim, Ekonomi Islam: Suatu Kajian Ekonomi Makro, Jakarta: The International Institute of Islamic Thought Indonesia Indonesia, 2002), hal. 19-22. 
1. Ketika keimanan ada pada tingkat yang cukup baik, maka motif berkonsumsi atau berproduksi akan didominasi oleh tiga motif utama tadi; mashlahah, kebutuhan dan kewajiban.

2. Ketika keimanan ada pada tingkat yang kurang baik, maka motifnya tidak didominasi hanya oleh tiga hal tadi tapi juga kemudian akan dipengaruhi secara signifikan oleh ego, rasionalisme (materialisme) dan keinginan-keinganan yang bersifat individualistis.

3. Ketika keimanan ada pada tingkat yang buruk, maka motif berekonomi tentu saja akan didominasi oleh nilai-nilai individualistis (selfishness); ego, keinginan dan rasionalisme.

Demikian pula dalam konsumsi, Islam memposisikan sebagai bagian dari aktifitas ekonomi yang bertujuan mengumpulkan pahala menuju falab (kebahagiaan dunia dan akherat). Motif berkonsumsi dalam Islam pada dasarnya adalah mashlabab (public interest or general human good $)^{7}$ atas kebutuhan dan kewajiban.

Sementara itu Yusuf Qardhawi ${ }^{8}$ menyebutkan beberapa variabel moral dalam berkonsumsi, di antaranya; konsumsi atas alasan dan pada barang-barang yang baik (halal), berhemat, tidak bermewah-mewah, menjauhi hutang, menjauhi kebakhilan dan kekikiran. Dengan demikian aktifitas konsumsi merupakan salah satu aktifitas ekonomi manusia yang bertujuan untuk meningkatkan ibadah dan keimanan kepada Allah SWT dalam rangka mendapatkan kemenangan, kedamaian dan kesejahteraan akherat (falab), baik dengan membelanjakan uang atau pendapatannya untuk keperluan dirinya maupun untuk amal shaleh bagi sesamanya. Sedangkan pada perspektif konvensional, aktifitas konsumsi sangat erat kaitannya dengan maksimalisasi kepuasan (utility).

Sir John R. Hicks ${ }^{9}$ menjelaskan tentang konsumsi dengan menggunakan parameter kepuasan melalui konsep kepuasan (utility) yang tergambar dalam kurva

${ }^{7}$ Mashlabah secara bahasa beratti kebergunaan (utilit) atau kesejahteraan (welfare), yang oleh Abu Hamid Al Ghazali (505 F/1111 M) dan Abu Ishaq Al Shatibi (790 H/1388 M) masalib (plural of Mashlahah) dibagi menjadi tiga kategori; esensial (essential/daruriyah), pelengkap (complententary/ bajjijab) dan keinginan (desirable/tabsiniyah). Dan tugas negatalah yang memastikan kemashlahatan kategoxi pertama dari masyarakat itu terpenuhi dengan baik. Lihat Muhammad Aktam Khan, (1997) "The Role of Government in the Economy", dalam The American Journal of Islamic Social Sciences, Vol. 14, No. 2, hal. 157.

${ }^{8}$ Yusuf Qardhawi, Peran Nilai dan Moral dalan Perekanomian Islam, (Jakarta: Rabbani Press, 1995).

${ }^{9}$ Lihat, Sadono Sukirno, Pengantar Teori Mikroekonomi, (Jakarta: Rajawali Press Jakarta, 2002). 
indifference (tingkat kepuasan yang sama). Hicks mengungkapkan bahwa individu berusaha memenuhi kebutuhan hidupnya melalui aktifitas konsumsi pada tingkat kepuasan yang maksimal menggunakan tingkat pendapatannya (income sebagai budget constraint).

\section{Ayat-ayat Konsumsi}

Dalam al-Qur'an ajaran tentang konsumsi dapat diambil dari kata kulâ dan isyraba terdapat sebanyak 21 kali. Sedangkan makan dan minumlah (kulu wasyrabu) sebanyak enam kali. Jumlah ayat mengenai ajaran konsumsi, belum termasuk derivasi dari akar kata akala dan syaraba selain fi'il amar di atas sejumlah 27 kali. $^{10}$

Dalam al-Qur'an, di antara ayat-ayat yang mengandung nilai ajaran konsumsi berdasar kata kunci dan kandungan makna konsumsi adalah sebagai berikut: (a) alBaqarah ayat $57,58,60-61,168,172-174,188$; (b) al-Nisa ayat $6,10,29$; (c) alMaidah ayat 3, 88, 96; (d) al-An'an ayat 118-121,141-142; (e) al-A'raf ayat 31-32; (f) at-Taubah ayat 34; (g) Yusuf ayat 47-48; (h) Hijr ayat 3; (i) al-Nahl ayat 114, 115; (j) al-Ista ayat 26-29; (k) Toha ayat 81 ; (l) al-Mu'minun ayat 51 ; (m) al-Furqan ayat $7-$ $8,20,67$; (n) as-Syuara ayat 79; (o) al-Mulk ayat 15; (p) al-Mursalat ayat 46. Selain ayat-ayat itu, masih banyak ayat-ayat lain tentang konsumsi dalam al-Qur'an yang dapat diambil dari akar kata syaraba, akbada, dan lain-lain. Karena keterbatasan kesempatan, hanya ayat-ayat tersebut yang akan dijadikan focus kajian tulisan ini.

Sebagaimana diurai di atas tentang tahapan metode tafsir, ayat-ayat tersebut dipilah menjadi kelompok surat Makkiyah dan Madaniyah sebagai berikut: 1988).

${ }^{10}$ Lihat Muhammad Fu'ad Abdul Baqi, Mu'jam Mrfabras li affadq al-Qur'an, (Qahirah: Dar al-hadis, 


\section{Tabel 1}

Klasifikasi Makkiyah dan Madaniyah

\begin{tabular}{|c|l|c|l|}
\hline No & \multicolumn{1}{|c|}{$\begin{array}{c}\text { Surat Makkiyyah } \\
\text { dan ayatnya }\end{array}$} & No & \multicolumn{1}{|c|}{ Surat Madaniyah dan ayatnya } \\
\hline 1 & Yusuf: $47-48$ & 1 & $\begin{array}{l}\text { al-Baqarah: } 57,58,60-61,168, \\
172-173,188\end{array}$ \\
\hline 2 & Hijr: 3 & 2 & al-Nisa: 6, 10, 29 \\
\hline 3 & al-Nahl: 114,115 & 3 & al-Maidah: 3, 88, 96 \\
\hline 4 & al-Isra: $17,26-29$ & 4 & at-Taubah: 34 \\
\hline 5 & Toha: 81 & & \\
\hline 6 & al-Mukminun: 51 & & \\
\hline 7 & al-Furqan: $7-8,20,67$ & & \\
\hline 8 & as-Syuara: 79 & & \\
\hline 9 & al-Mulk: 15 & & \\
\hline 10 & al-Mursalat 43,46 & & \\
\hline
\end{tabular}

Dati pemilahan tersebut, terlihat bahwa ayat-ayat konsumsi lebih banyak yaitu 22 ayat pada 10 surat diturunkan pada periode Makkah atau sebelum Hijrah Nabi. Sedangkan di Madinah 16 ayat pada 4 surat. Hal ini mengandung indikasi bahwa alQur'an mempunyai perhatian yang tinggi tentang konsumsi seiring tahapan pemberlakuan ajaran-ajaran Islam yang betsifat fundamenal. Dengan banyaknya ayat alQur'an tentang konsumsi, maka mempunyai implikasi bahwa ajaran ekonomi Islam. diletakkan fondasi-fondasinya pada periode awal Islam.

Setelah dipilah berdasar kelompok Makkiyah dan Madaniyah, ayat-ayat dan surat tersebut, apabila dirunut berdasar urutan turunnya surat al-Qur'an. Pemilihan ini dimaksudkan untuk melihat tahapan-tahapan pemberlakuan ajaran al-Qur'an tentang konsumsi. Secara logika, apa yang turun terdahulu akan bersifat fundamental sedangkan yang turun belakangan merupakan penjelasan selanjutnya dan biasanya lebih bersifat operasional. Data urutan turunnya surat al-Qur'an didasarkan pada data mushaf Rabithah al alam al-Islami, al-Qur'an al-Karim dan Abu Abdillah al-Zanzani, Tarikb al-Qur'an. " Dari urutan tersebut, kronologis surat-surat yang di dalamnya terdapat ayat-ayat konsumsi adalah sebagai berikut:

${ }^{11}$ Dikutip dart lampiran buku Abd Muin Salim, Konsepsi Kektasaan Politik dalam al-Qur'an, Jakarta: LSIK, 1994), hal. 329-330. 


\section{Tabel 2}

Kronologis ayat-ayat konsumsi

\begin{tabular}{|c|l|c|l|}
\hline $\begin{array}{c}\text { No } \\
\text { urut }\end{array}$ & \multicolumn{1}{|c|}{ Makkiyyah } & $\begin{array}{c}\text { No } \\
\text { urut }\end{array}$ & \multicolumn{1}{|c|}{ Madaniyyah } \\
\hline 33 & al-Mursalat: 43,46 & 87 & $\begin{array}{l}\text { al-Baqaah: } 57,58,60- \\
61,168,172-173,188\end{array}$ \\
\hline 39 & al-A'taf: 31-32 & 92 & al-Nisa: $6,10,29$ \\
\hline 42 & al-Furqan: $7-8,20,67$ & 112 & al-Maidah: 3, 88, 96 \\
\hline 45 & Toha: 81 & 113 & at-Taubah: 34 \\
\hline 47 & as-Syuara: 79 & & \\
\hline 50 & al-Isra: $16,26-29$ & & \\
\hline 53 & Yusuf: $47-48$ & & \\
\hline 54 & Hijr: 3 & & \\
\hline 55 & $\begin{array}{l}\text { al-An'an: } 118-121,141- \\
\text { 142 }\end{array}$ & & \\
\hline 70 & al-Nahl: $69,114,115$ & & \\
\hline 74 & al-Mu'minun: 51 & & \\
\hline 77 & al-Mulk: 15 & & \\
\hline
\end{tabular}

\section{E. Prinsip-prinsip Konsumsi al-Qur'an}

Tahap selanjutnya, dari metodologi tafsir ekonomi al-Qur'an ini adalah menafsirkan ayat-tersebut dengan pendekatan adabi al-ijtimâ'i wal iqtishâdiyab. Tahapan ini dimaksudkan untuk dapat mengambil prinsip-prinsip konsumsi.

Pada ayat 43 surat al-Mursalat Allah memerintahkan untuk makan dan minum dengan enak sebagai akibat dari apa yang telah dikerjakan oleh manusia. Ayat ini dihubungkan dengan ayat sebelumnya yaitu 41 menggambarkan tentang balasan untuk orang-orang yang bertakwa yaitu dalam naungan yang teduh dan disekitar mata air. Kemungkinan besar hal ini menggambarkan kehidupan di sjurga atau kehidupan yang sejahtera dan bahagia di dunia bagi orang-orang yang bertakwa sebagai balasan Allah pada orang-orang yang baik.

Sebaliknya pada ayat 46, Allah memperingatkan kepada orang-orang kafir yang mendustakan kebenatan bahwa kehidupan di dunia dengan segala kesenangannya hanya waktu yang pendek saja. Walaupun mereka dapat makan dan minum dengan enak, tetapi nasib orang-orang yang mendustakan kebenaran tetaplah berada dalam kecelakaan. Kesenangan dan kenikmatan dari segala yang dikonsumsi di dunia hanyalah berada dalam waktu yang pendek saja.

Pada tahapan berikutnya, yaitu pada surat al-A'raf: 31-32 terkait konsumsi Allah SWT memperingatkan kepada umat manusia untuk mergunakan apa-apa yang 
dapat digunakan seperti pakaian dan lain-lain secara proporsional dan tidak berlebihlebihan.

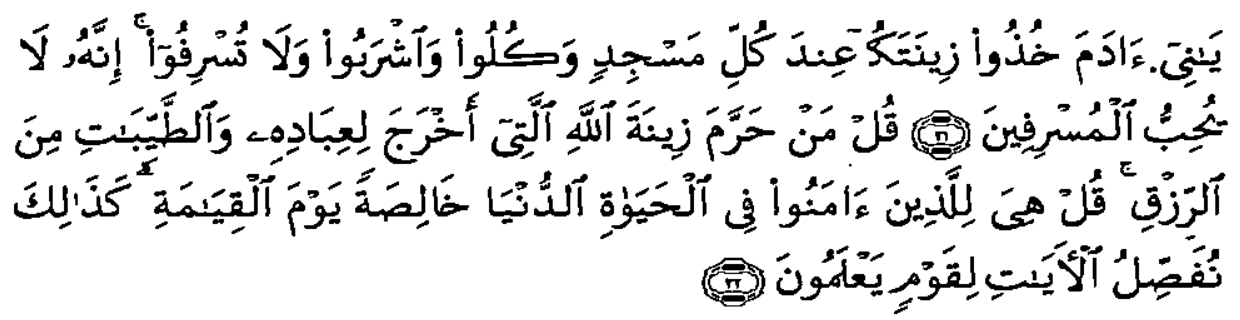

21. Hai anak Adam, pakailab pakaianmu yang indah di setiap (memasuki) mesjid, makan dan minumlah, dan janganlab berlebih-lebiban. Sesunggubnya Allab tidak menyukai orang-orang yang berlebih-lebihan. 22. Katakanlah: "Siapakah yang mengharamkan perhiasan dari Allab yang Telab dikeluarkan-Nya untuk bamba-bamba-Nya dan (siapa pulakab yang mengharamkan) rezki yang baik?" Katakanlab: "Semuanya itu (disediakan) bagi orang-orang yang beriman dalam kehidupan dunia, khusus (untuk mereka saja) di hari kiamat." Demikianlab kami menjelaskan ayat-ayat itu bagi orang-orang yang Mengetabui.

Ayat ini turun terkait kejadian beberapa sahabat Nabi bermaksud meniru kelompok al-Hummas yaitu kelompok Quraisy yang menggebu-gebu semangat beragamanya sehingga tidak mau berthawaf kecuali memakai pakaian baru yang belum pernah dipakai melakukan dosa, serta sangat ketat dalam memilih makanan dan kadarnya selama melaksanakan ibadah haji. Ayat itu dengan demikian merupakan teguran Allah SWT atas perilaku umat yang berlebih-lebihan dalam beribadah datam hubungannya dengan penggunaan pakaian.

Menurut Quraisy Shihab, ayat 31 tersebut mengandung makna keharusan memakai pakaian yang indah dan patut serta menutupi aurat. Penggunaan pakaian ini ketika setiap memasuki masjid atau di dalam masjid, baik dalam arti khusus maupun mesjid dalam pengertian luas yaitu bumi Allah. Makanlah yang halal, enak, bermanfaat lagi bergizi dan berakibat baik pada tubuh. Minumlah minuman yang kamu sukai tetapi tidak memabukkan dan tidak mengganggu kesehatan. Janganlah berlebih-lebihan, karena Allah tidak menyukai otang yang berlebihan yakni tidak memberikan rahmat dan pahala bagi orang-orang yang betlebihan. ${ }^{12}$ Dengan demikian, dari ayat di atas dapat diambil prinsip konsumsi yaitu proporsional dan tidak berlebiblebihan atau tidak mengikuti selera bawa nafsu.

Tidak bermaknanya berlebih-lebihan dalam kebaikan dan keharusan bersikap wajar dalam konsumsi ditegaskan lagi ketika Allah SWT menggambarkan sifat Nabi

${ }^{12}$ M. Quraisy Shihab, Tofsir Al-Misbab Pesan, Kesan dan Keserasian al-Qur'an, volume 5, (Jakarta: Lentera Hati, 2003), hlm 75-76. 
Muhammad sebagai utusan yang juga bersifat manusiawi, yaitu makan dan minum, melakukan kegiatan ekonomi di pasar. Nabi Muhammad bukanlah malaikat yang tidak makan dan tidak minum. Demikian kandungan surat al-Furqan: 7-8, 20.

Sedangkan pada surat al-Furqan ayat 67 , Allah menggambarkan sikap konsumsi yang baik adalah tidak berlebih-lebihan dalatm membelanjakan harta benda dan tidak pula kikir, melainkan pertengahan di antara keduanya. Pertengahan ini disini tampaknya dapat dimaknai sepadan dan proporsional, dalam pengertian tidak besar pasak dari pada tiang;

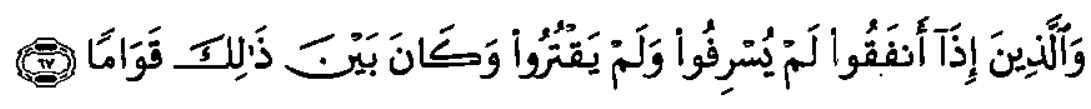

67. Dan orang-orang yang apabila membelanjakan (harta), mereka tidak berlebiban, dan tidak (pula) kikir, dan adalah (pembelanjaan itu) di tengab-tengab antara yang demikian.

Dengan demikian dari ayat 67 al-Furqan dapat diambil prinsip konsumsi yaitu sepadan yaitu tidak besar pasak dari pada tiang. Demikian pula hal ini diperkuat oleh QS. Toha: 81 yang menyatakan makanlah yang baik-baik dari karunia rezeki Allah tetapi janganlab melampaui batas dari ukuran karunia rezeki Allab tersebut sehingga Allah dapat menimpakan kemutkaan-Nya. Di sinilah tercermin prinsip konsumsi menerima dengan sikap syukur terhadap rezeki Allah, karena secara hakiki, sesungguhnya Allah-lah yang memberi makan dan minum (QS. as-Syuara: 79)

Demikian pula kemudian ditegaskan oleh QS al-Isra': 26-29.

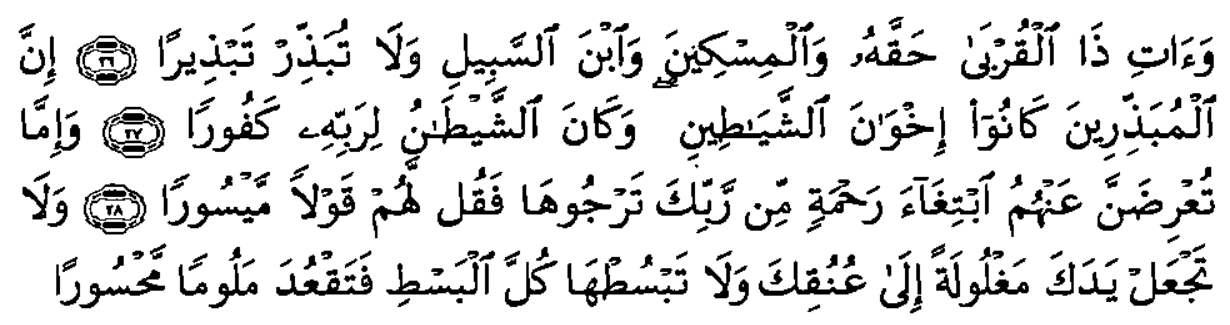

26. Dan berikanlah kepada keluarga-keluarga yang dekat akan baknya, kepada orang miskin dan orang yang dalam perjalanan dan janganlah kamu menghambur-bamburkan (bartamu) secara boros. 27. Sesunggubnya pemboros-pemboros itu adalab Saudara-saudara setan dan setan itu adalab sangat ingkar kepada Tubaninya. 28. Dan jika kamu berpaling dari mereka sntuk memperoleb rahmat dari Tuhanmu yang kamu harapkan, Maka Katakanlah kepada mereka Ucapan yang pantas 29. Dan janganlab kamu jadikan tanganmu terbelenggu pada lehermu dan janganlab kamu terlalu mengulurkannya Karena itu kamu menjadi tercela dan menyesal. 
Keempat ayat di atas memberi pelajaran tentang konsumsi dalam beberapa hal. Pertama, merupakan suatu kebajikan memberikan hal jaminan hidup yaitu pemenuhan kebutuhan primer kepada keluarga, kerabat, orang miskin dan ibn sabil. Kedua, tidak bersikap boros, karena sikap boros merpakan perilaku setan. Ketiga, tidak bersikap kikir dan juga tidak melebihi batas kemampuan dalam berinfaq. Dengan demikian dari keempat ayat di atas dapat diambil prinsip konsumsi yaitu mendukung pemenuban kebutuhan primer keluarga, kerabat, miskin dan ibn sabil, dan tidak boros lagi tidak kikir melainkan sesuai kemampuan.

Pada surat Yusuf: 47-48, berdasar pada kisah Nabi Yusuf tentang pola konsumsinya, kita dapat mengambil prinsip konsumsi yang hemat. Yaitu mempertimbangkan kebutuhan pada masa depan. Hal ini tercermin pada kebijakan ekonomi Nabi Yusuf yang menaman gandum seperti biasa, kemudian menyimpannya dengan tangkai dan bulirnya, serta mengkonsumsinya secara hemat agar dapat menghadapi kebutuhan masa depan yang sulit. Demikian pula apabila suatu masyarakat mempunyai sikap konsumsi yang menuruti selera kesenangan dan hawa nafsu sehingga dilalaikan oleh angan-angan yang kosong maka akan berakibat merugikan pada masa depan. Demikian kandungan QS. al-Hijr: 3.

Karena itu dalam proses dan operasional konsumsi harus mengindahkan aturanaturan yang ditetapkan. Di antara aturan main konsumsi al-Qur'an terkandung dalam QS. al-An'am: 118-121 dan 140-141, di antaranya, hanya memakan binatang ternak yang disembelih dengan nama Allah, tidak mengkonsumsi apa-apa yang telah diharamkan Allah, tidak menuruti hawa nafsu dalam konsumsi, mengeluarkan zakat pertanian dan peternakan ketika memetik hasil daripadanya dan tidak mengikuti langkah-langkah setan. Karena setan merupakan musuh yang nyata bagi manusia. Dengan demikian, dari ayat-ayat di atas dapat diambil prinsip taat aqas atau taat bukum dalam konsumsi.

Sesudah al-Qur'an mengajarkan tentang konsumsi melalui kesembilan tahapan ayat-ayat di atas, kemudian Allah menegaskan kembali tentang ajaran konsumsi melalui surat al-Nahl: 114,115 . Pada ayat ini baru disebut kata balal yang digandeng dengan thayyib. A pabila dihubungkan dengan urutan turunnya surat an-Nahl yang turun ke 70 di Makkah, maka dapat disimpulkan bahwa pemberlakukan istilah halal baru dilakukan pada akhir episode turunnya al-Qur'an periode Makkiyah. 


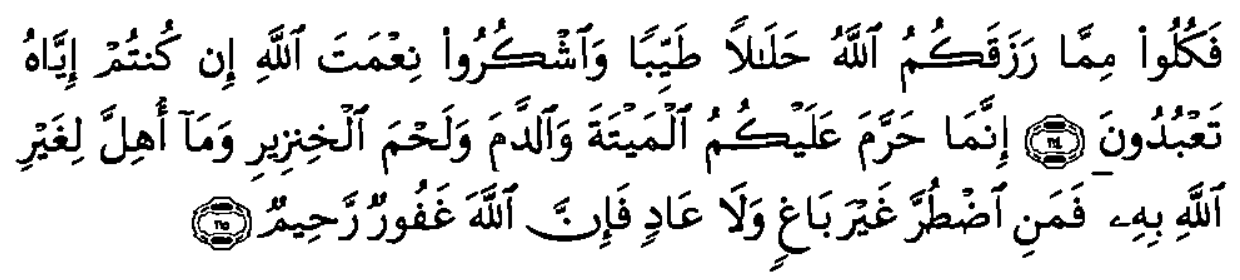

114. Maka makanlah yang halal lagi baik dari rezki yang Telah diberikan Allah kepadamu; dan syukurizlah nikmat Allah, jïea kamu Hanja kepada-Nya saja menyembah.115. Sesunggubnya Allab Hanya mengharamkan atasmu (memakan) bangkai, darab, daging babi dan apa yang disembelih dengan menyebut nama selain Allab; tetapi barangsiapa yang terpaksa memakannya dengan tidak menganiaya dan tidak pula melampaui batas, Maka Sesunggubnya Allab Maba Pengampun lagi Maba Penyayang.

Pada ayat di atas, Allah memberlakukan syarat halal dan baik untuk apa-apa yang boleh dikonsumsi dan memerintahkan agar bersyukur atas nikmat yang diberikan Allah disertai pengandaian jika hanya kepada Allah saja beribadah. Dengan demikian, pada ayat 114-115 surat an-Nahl terdapat prinsip konsumsi balal dan baik serta selalu bersyukur. Perintah konsumsi itu, tidak hanya ditujukan kepada umum, tetapi ditujukan pula kepada para Rasul. Hal ini tercermin dalam surat al-Mukminun: 51. "Hai rasul-rasul, makanlah dari makanan yang baik-baik, dan kerjakanlah amal yang saleh. Sesungguhnya Aku Maha mengetahui apa yang kamu kerjakan".

Pada ayat terakhir surat Makkiyah tentang konsumsi yaitu QS. al-Mulk: 15 Allah menegaskan bahwa Allah-lah yang menjadikan untuk kamu sekalian bumi menjadi mudah, karena itu berusahalah dimana pun dan makanlah dari rezeki Allah. Sesungguhnya kamu sekalian pasti kembali kepada Allah. Kepastian bahwa semua manusia akan kembali kepada Allah, dalam konteks konsumsi dapat diambil prinsip pettangungjawaban, yaitu babwa apapun yang kita konsumsi pasti akan mempunyai dampak pada tubub manusia dan perilakunya.

Dari paparan di atas, dapat dicatat bahwa prinsip-prinsip konsumsi yang diturunkan pada peride surat Makkiyah lebih mendasarkan pada ajaran-ajaran fundamentalnya yaitu meliputi; makan minumlah yang enak dari basil pekerjaan atau usaha dan peringatan tentang babwa kenikmatan dan kesenangan di dunia itu banya sebentar (QS. al-Mursalat: 43 dan 46), arahan untuk melakukan konsumsi secara proporsional dan tidak berlebih-lebiban atau tidak mengikuti selera hawa nafsu (QS. al-A'raf: 31-32). Perilaku konsumsi barus sepadan yaitu tidak besar pasak dari pada tiang (QS. al-Furqan: 67) yaitu menerima dengan sikap syukur dan melakukan konsumsi yang baik dari karunia rezeki Allah yaitu tidak melampaui batas dari reqeki yang telab diberikan (QS. Toha: 81) sesunggubnya Allab-lab yang memberi makan dan minum.(QS. as-Syuara: 79). 
Kemudian ingatlah bahwa dalam konsumsi tidak hanya melakukan pemenuban kebutuban pribadi tetapi barus melakukan pemenuban kebutuban primer keluarga, kerabat, miskin dan ibn sabil, serta tidak boros dan tidak kikir melainkan sesuai kemampuan (QS. al-Isra': 26-29). Karena itu konsumsi harus dilakukan dengan hemat. Hal ini berdasar pada kisah Nabi Yusuf (QS. Yusuf: 47-48).

Sebaliknya apabila tidak hemat, melainkan menuruti selera kesenangan dan hawa nafsu sehingga lalai oleh angan-angan maka akan merugikan pada masa depannya (QS. al-Hijr: 3). Karena itu pula dalam proses operasionalnya perilaku konsumsi harus taat pada azas hukum misalnya hanya mengkonsumsi binatang ternak yang disembelih dengan menyebut nama Allah, tidak mengkonsumsi yang diharamkan, tidak menuruti hawa nafsu dan mengeluarkan zakat ketika panen serta tidak mengikuti langkah setan.

Taat azas yang dimaksud tidak hanya secara formal semata dalam pengertian halal dzatiahnya semata, melainkan meliputi kandungan azas filosofis, karena itu pada QS. an-Nahl: 114-115, konsumsi harus dilakukan secara halal dan baik. Halal di sini bermaksud halal dzatiahnya, sebagaimana apa-apa yang dihalalkan oleh alQur'an. Baik yang dimaksud adalah baik akibat dari padanya. Setelah penetapan prinsip ini kemudian ditegaskan pula bahwa dalam konsumsi terdapat pritssip pertangungjawaban yaitu apapun yang dikonsumsi pasti akan mempunyai dampak pada tubub manusia dan perilakunya (QS. al-Mulk:15).

Bagaimanakah kandungan yang terdapat dalam ayat-ayat konsumsi yang terdapat dalam surat-surat Madaniyah? Sebagaimana dijelaskan pada bagian awal, ayat-ayat konsumsi yang terdapat dalam surat-surat Madaniyah berjumlah lebih sedikit yaitu 16 ayat pada 4 surat. Apa hikmah di balik fakta ini?

Pada QS. al-Baqarah: 57, 58 dan 60-61, al-Qur'an menegaskan kekuasaan Allah yang memberikan nikmat al-mann dan as-salwâ kepada Bani Israil ketika mereka berada dalam ketersesatan antara Syam, Syuriah, Lebanon, dan Mesir sekarang, hingga kemudian dapat memasuki kota Baitul Maqdis yang subur. Selain nikmat manna dan salwâ, pada ayat 60-61 Allah telah menganugerahkan 12 mata air dari mu'jizat Nabi Musa yang menjadi mata air kehidupan bagi anak cucu Nabi Ya'kub. Namun sayangya kaum Nabi Musa, meskipun telah dikaruniai nikmat yang banyak selalu merasa tidak cukup. Makanan berupa burung, manisan bagaikan madu mereka tolak dan malah meminta diganti oleh sayuran mayut. Itulah sebabnya mereka ditimpa kehinaan dan kesedihan karena mereka tamak dalam meraih gemerlapnya duniawi. ${ }^{13}$ 
Pada ayat selanjutnya yaitu QS. al-Baqarah: 168 Allah menegaskan kepada umat manusia untuk melakukan konsumsi hanya yang halal dan baik dan jangan mengikuti langkah-langkah setan:

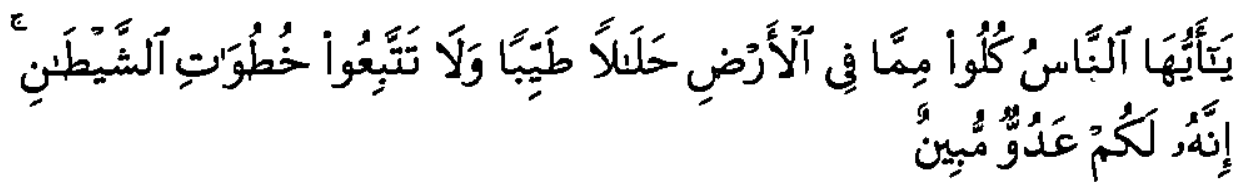

168. Hai sekalian manusia, makanlah yang halal lagi baik dari apa yang terdapat di bumi, dan janganlah kamu mengikuti langkah-langkah setan; Karena Sesungguhnya setan itu adalah musub yang nyata bagimu.

Setan mempunyai jejak langkah yang dapat menjerumuskan manusia dan makanan minuman dapat menjadi media setan untuk mengelabui manusia agar masuk dalam perangkap setan. Penegasan hal ini, pada dasarnya untuk mengingatkan dahulu kala, bagaimana Adam dan Hawa terjerembab ke dalam tipu daya dan rayuan setan melalui makanan.

Dengan demikian pada ayat 168 itu terdapat prinsip konsumsi halal dan baik serta tidak boleh mengikuti langkah setan dalam pengertian mengikuti hawa nafsu. Selera atau hawa nafsu dapat menjadikan sesuatu yang hanya merupakan keinginan (want), dapat menjadi seperti kebutuhan (need). Pada konteks inilah, perilaku konsumsi pada dasanya harus sesuai dengan kadar atau standar kebutuhan dan bukan standar keinginan. Penyebutan halal dan baik pada ayat ini merupakan penegasan kembali penetapan halal dan baik yang ditetapkan pada surat an-Nahl: 114 yang diturunkan pada akhir periode Nabi sebelum melakukan hijrah dari Makkah ke Madinah.

Pada ayat 172-173 al-Qur'an secara spesifik mengajak kepada orang-orang yang beriman untuk hanya melakukan konsumsi yang baik-baik dati karunia rezeki Allah disertai rasa syukur hanya kepada Allah atas nikmat yang telah diberikan Allah kepada kita. Pada ayat selanjutnya, yaitu 173 dijelaskan secara cukup rici apa-apa yang diharamkan meliputi bangkai, darah yang mengalir, daging babi dan sembelihan yang tidak disebut nama Allah. Dalam ayat ini terkesan hanya yang disebutkan saja yang haram, tetapi tidak demikian. Pada konteks inilah kemudian dijelaskan oleh hadishadis.

Adalah menarik pandangan Hasa'n Raid (2001) seperti dikutip Anom Surya Putra, yang dimaksud darah yang mengalir tidak semata-mata bermakna memakan darah yang mengalir dalam pengertian dhahir Memakan darah yang mengalir, termasuk 
di dalamnya menghisap dan memeras sesama manusia, seperti penghisapan tenaga buruh oleh para pemodal dalam sistem ekonomi yang berpihak pada kaum pemodal dan penguasa. ${ }^{14}$

Setelah al-Qur'an menjelaskan secara lebih rinci tentang apa yang halal dan apa yang haram, lebih lanjut al-Qur'an menegaskan tentang konsumsi secara lebih luas pada hubungan antara individu yakni hubungan bisnis dan investasi yang harus dinaungi oleh landasan etika. Demikian, pula apabila terjadi perselisihan tentang harta benda jangan sampai menyelesaikannya dengan cara-cara manipulasi politik kekuasaan (QS. al-Baqarah: 188) menegaskan:

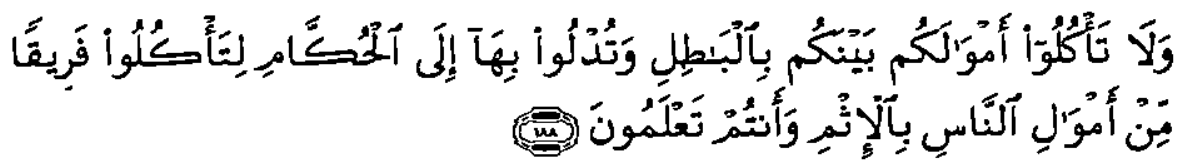

188. Dan janganlah sebahagian kamu memakan harta sebabagian yang lain di antara kamu dengan jalan yang batbil dan (janganlab) kamu membava (urusan) harta itu kepada hakim, supaya kamu dapat memakan sebahagian daripada barta benda orang lain itu dengan (jalan berbuat) dosa, padabal kamu Mengetabui.

Ayat ini berdasar konteksnya mengharuskan adanya hubungan kerja sama bisnis yang saling menguntungkan. Apabila dua pihak bekerja sama dalam situasi, proses dan hasil yang tidak seimbang, maka kerja sama itu menjadi batil. Kandungan ayat ini seirama dengan ayat konsumsi dalam bingkai kerjasama pada surat an-Nisa: 29. Tujuan kerja sama bisnis adalah mencapai tujuan yang disepakati yaitu saling menguntungkan. Larangan mengadu kepada pengadilan untuk memenangkan perkara dengan cara menyogok hakim adalah perbuatan yang sangat dilarang dalam ayat ini. Dengan demikian, dari ayat ini dapat diambil prinsip konsumsi yaitu saling menguntungkan berdasarkan aqaz keadilan.

Pada tahapan selanjutnya yaitu dalam surat an-Nisa: ayat 6 dan 10 menjelaskan tentang pola manajemen harta anak yatim. Harta anak yatim, kerap kali diamanahkan kepada wali yang disepakai, baik wali karena hubungan darah atau wali yang diangkat oleh pengadilan. Wali penerima amanah harus melakukan pengelolaan harta anak yatim secara baik dan aman dari sisi kerugian sampai anak yatim itu mencapai usia baligh. Dari upayanya itu maka si wali boleh mengambil manfaat atau keuntungan yang wajar sebagai ujrah, tetapi tidak berlebihan.

${ }^{14}$ Pandangan Hasan Raid ini merupakan tafsir atas QS. al-An'an: 145. Lihat Anom Surya Putra, "Man ista'jara ajran fal yu'alimbu ajrabu”. www. nu.online. Diakses 14 Januari 2008. 
Demikian pula, pada ayat 10 menegaskan bahwa:

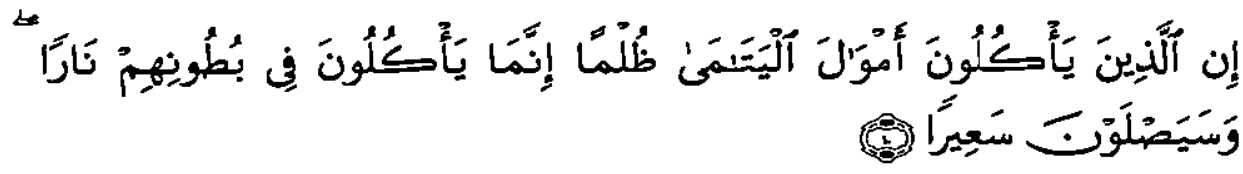

10. Sesunggubmya orang-orang yang memakan harta anak yatim secara zalim, Sebenarnya mereka itu menelan api sepenuh perutnya dan mereka akan masuk ke dalam api yang menyala-nyala (neraka).

Ancaman pada orang-orang yang melakukan perilaku konsumsi secara dzalim sama saja dengan mengkonsumsi api ke dalam perutnya dan dimasukkan ke dalam neraka yang menyala-nyal punyai. Ancaman ini sangat tegas dan keras. Dengan demikian, al-Qur'an menghendaki perilaku konsumsi yang jaub dari kedzaliman atau tidak mengandung kedzaliman. Inilah prinsip konsumsi dari ayat 10 surat an-Nisa.

A pabila kerjasama dalam pengelolaan dan pengembangan harta benda pada ayat 6 dan 10 surat annisa terbatas dalam bingkai keluarga yang terkait hubungan darah, maka pada ayat 29 al-Qur'an secara lebih luas menegaskan tentang perilaku konsumsi dalam bingkai kerjasama pengelolaan dan pengembangan harta benda secara umum.

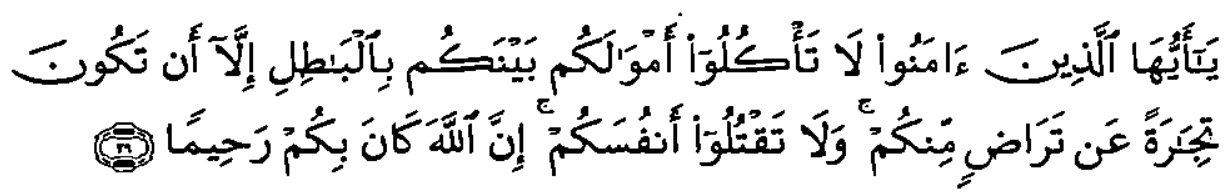

29. Hai orang-orang yang beriman, janganlab kamu saling memakan barta sesamamu dengan jalan yang batil, kecuali dengan jalan permiagaan yang berlaku dengan suka sama-suka di antara kamu. dan janganlab kamu membunub dirimu; Sesunggubnya Allab adalab Maba Penyayang kepadamu.

Menurut al-Maraghi ayat ini merupakan kaidah umum tentang transaksi dalam masalah harta benda sebagai upaya pembersihan jiwa di dalam mengumpulkan harta yang dicintai. ${ }^{15}$ Mengambil harta benda, menggunakan atau bahkan mengkonsumsinya diperbolehkan asalkan tidak terdapat kebatilan di dalam prosesnya. Perilaku mengambil harta tanpa pengganti, tanpa kerelaan pemiliknya, atau menggunakan dan mendayagunakan harta benda bukan pada jalan yang benar adalah perilaku konsumsi yang tidak dikehendaki oleh ayat ini. Batil adalah segala

${ }^{15}$ Lihat Lukman Fauroni, Etika Birnis dalan al-Qur'an, (Yogyakarta: Pustaka Pesantren, 2006), hal $104-105$. 
sesuatu yang keliru, yang batil, yang sia-sia, yang tidak ada manfaat ${ }^{16}$ atau lawan dari kebenaran yaitu segala sesuatu yang tidak mengandung apa-apa, tidak mengandung manfaat di dalamnya walaupun setelah diteliti. ${ }^{17}$

Secara nyata dalam ayat tersebut, ditegaskan janganlah kamu sekalian saling memakan harta benda di antara kamus sekalian dengan jalan yang mengandung kebatilan. Menurut Qurasih Shihab, makan merupakan kebutuhan pokok manusia, apapun usaha dan kerja yang dilakukan pada dasarnya adalah untuk digunakan yang sebagiannya dimakan. Apabila makan saja yang merupakan kebutuhan primer terlarang denan cara yang mengandung kebatilan, tentu lebih terlarang lagi untuk pemenuhan kebutuhan manusia yang bersifat sekunder dan tertier. ${ }^{18}$ Pada ayat ini yang harus dijauhkan dati perilaku muslim bukan hanya dalam konteks individual tetapi juga dalam konteks hubungan antar individu seprti kerja sama atau bersamasama seperti dalam keseluruhan proses pabrikasi. Inilah makna dari kata bainakum dari ayat tersebut. Dengan demikian, dari ayat ini dapat diambil prinsip konsumsi yaitu tidak mengandung kebatilan dalam konsumsi

Kemudian pada surat al-Maidah: 3, sebagai bagian kecil dari contoh nyata makanan yang mengandung kebatilan, ditegaskan apa-apa yang diharamkan. Apabila dalam surat an-Nahl: 114-115 yang turun pada periode Makkiyah akhir ditegaskan, "Makanlah yang halal dan baik dari rezeki yang Kami berikan kepadamu...... Sesungguhnya Allah hanya mengharamkan atas kamu memakan bangkai, darah, daging bagi dan binatang yang disembelih dengan menyebut nama selain Allah", maka pada pada ayat 3 surat al-Maidah ditegaskan dengan penegasan yang lebih rinci sebagai berikut:

Dibaramkan bagimu (memakan) bangkai, darab daging babi, (daging bewan) yang disembelih atas nama selain Allah, yang tercekik, yang terpuksul,yang jatuh, yang ditanduk, dan diterkam binatang btas, kecuali yang sempat kamu menyembelibnya, dan (diharamkan bagimu) yang disembelih untuk berbala. Dan (diharamkan juga) mengundi nasib dengan anak panah, (mengundi nasib dengan anak panah itu) adalah kefasikan. Pada bari ini orang-orang kafir telah putus asa untuk (mengalabkan) agamamu, sebab itu janganlah kamu takut kepada mereka dan takutlah kepada-Ku. Pada hari ini telab Kusempurnakan untuk kamu agamamu, dan telab kucukspkean kepadamu nikmat-Ku, dan telah Ku-ridhai Islam itu jadi agama bagimu. Maka barang siapa terpaksa, karena kelaparan tanpa sengaja berbuat dosa, sesunggubnya Allah Maha Pengampun lagi Maba Penyayang.

${ }^{16}$ Ahmad Warson Munawir, Kamus al-Munawwir, hal. 99-100

${ }^{17}$ Lihat ar-Raghib al-Isfahani, al-Muffadat fi Gharib al-Qur'an, hal. 50-51

${ }^{18}$ Ibid, hal. 105 . 
Dengan demikian pemberlakuan konsumsi pada masyarakat yang sudah membudaya dengan kebiasaan-kebiasaan konsumsi yang keliru, dilakukan secara bertahap. QS. al-Maidah 3 ini diturunkan di Madinah, di mana komunitas muslim sudah mengalami perkembangan yang baik, dan keimanan masyarakat atas ajaran agamapun dimungkinkan telah lebih baik dari pada periode di Makkah. Demikianlah Allah secara bijaksana mengajarkan ajaran-Nya.

Perang batin antara mengikuti ajaran al-Qur'an dalam hal konsumsi dan kebiasaan mengakar yang sangat mungkin berlawanan dengannya, sangat mungkin terjadi. Karena itu Allah menegaskan kembali agar kukuh dalam melakukan perilaku konsumsi yang halal dan baik dengan ayat 88 dan 96 surat al-Maidah.

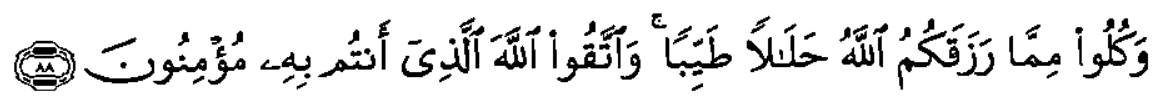

88. Dan makanlab makanan yang balal lagi baik dari apa yang Allab Telab rezekikan kepadamu, dan bertaktyalab kepada Allah yang kamu beriman kepada- $N y a$.

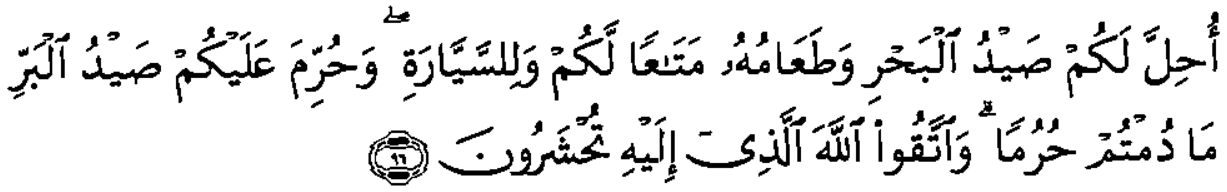

96. Dibalalkan bagimu binatang burnan laut dan makanan (yang berasal) dari laut sebagai makanan yang lezat bagimu, dan bagi orang-orang yang dalam perjalanan; dan dibaramkan atasmu (menangkap) binatang bunsan darat, selama kamu dalam ibram. dan bertakwalah kepada Allab yang kepada-Nyalah kamu akan dikumpulkan.

Melakukan perubahan kultur merupakan hal yang tidak mudah. Sangat mungkin ada di antara masyarakat muslim pada saat itu yang membanding-bandingkan dengan kebiasaan masyarakat Yahudi dan Nasrani sebagai komunitas religius yang sangat mungkin berbeda oleh sebab inskonsistensi mereka dengan ajaran yang aslinya. Karena itu al-Qư'an meneguhkan keraguan masyarakat muslim dengan QS at-Taubah: 34:

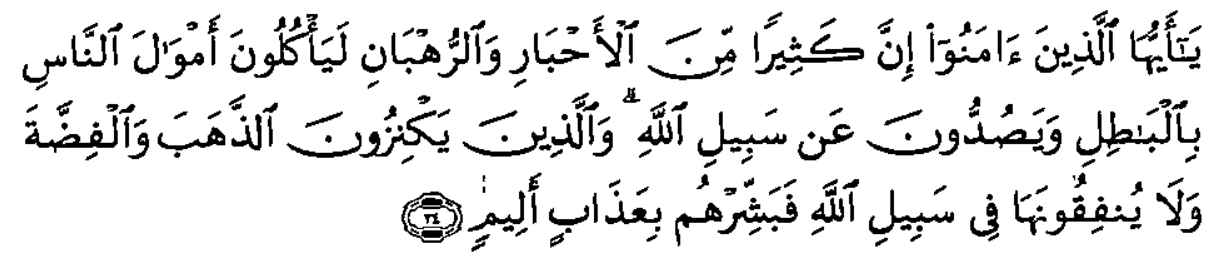

34. Hai orang-orangyang beriman, Sesungguhnya sebahagian besar dari orang-orang alim Yabudi dan rabib-rabib Nasrani benar-benar memakan barta orang dengan jalan batil dan mereka mengbalang-balangi (manusia) dari jalan Allah. dan orang-orang yang memyimpan emas dan perak 
dan tidak menafkabkannya pada jalan Allah, Maka beritahukanlab kepada mereka, (bahwa mereka akan mendapat) silksa yang pedih.

Ayat ini menggambarkan sikap buruk kehidupan kaum ahbar yaitu alim Yahudi dan rahib Nasrani yaitu loba dan tamak serta suka menumpuk harta benda yakni mengambil dan menggunakan harta orang lain dengan cara-cara yang batil seperti menyogok, memanipulasi ajaran untuk memperoleh keuntungan materi. Secara lahiriyah mereka menampakkan diri sebagai orang-orang alim yang dekat dengan Tuhan, tetapi hakikatnya kebalikan dari hal itu. ${ }^{19}$ Dengan demikian, prinsip konsumsi dari ayat ini adalah perilaku konsumen muslim barus jauh dari sifat-sifat loba, tamak, suka menimbun harta, mengambil barta orang lain dengan cara-cara yang batil bingga manipulasi ajaran agama untuk kepentingan barta benda.

\section{F. Penutup}

Dari pembahasan di atas terbukti, pemberlakukan ajaran Islam tentang konsumsi melalui ayat-ayat al-Qur'an dilakukan secara runtut, bertahap dan sistematis untuk membangun suatu komunitas yang bertradisikan konsumsi qur'ani.

Pada periode Makkiyah ditegaskan prinsip-prinsip konsumsi fundamental meliput; makan minumlah yang enak dari hasil pekerjaan atau usaha dan peringatan tentang bahwa kenikmatan dan kesenangan di dunia itu hanya sebentar (QS. alMursalat, 77: 43 dan 46), arahan untuk melakukan konsumsi secara proporsional dan tidak berlebih-lebihan atau tidak mengikuti selera hawa nafsu (QS. al-A'raf: 3132). Perilaku konsumsi harus sepadan yaitu tidak besar pasak dari pada tiang (QS. al-Furqan: 67) yaitu menerima dengan sikap syukur dan melakukan konsumsi yang baik dari karunia rezeki Allah yaitu tidak melampaui batas dari rezeki yang telah diberikan (QS. Toha:81) karena sesungguhnya Allah-lah yang memberi makan dan minum.(QS. as-Syuara: 79).

Dalam konsumsi tidak hanya melakukan pemenuhan kebutuhan pribadi tetapi harus melakukan pemenuhan kebutuhan primer keluarga, ketabat, miskin dan ibn sabil, serta tidak boros dan tidak kikir melainkan sesuai kemampuan(QS. al-Isra': 26-29). Karena itu konsumsi harus dilakukan dengan hemat (QS. Yusuf: 47-48).

Apabila tidak hemat, alias menuruti selera kesenangan, hawa nafsu dan lalai oleh angan-angan maka akan merugikan pada masa depan (QS. al-Hijr: 3). Karena itu proses operasional perilaku konsumsi harus taat pada azas hukum serta tidak

\footnotetext{
${ }^{19}$ M Quraish Shihab, ibid, vol 5 hal. 583
} 
mengikuti langkah setan yaitu hanya mengkonsumsi yang halal dan baik (QS anNahl: 114-115). Dalam Konsumsi terdapat prinsip pertangungjawaban yaitu apapun yang dikonsumsi pasti akan mempunyai dampak pada tubuh manusia dan perilakunya. (QS. al-Mulk: 15).

Kemudian pada periode Madaniyah, mengukuhkan prinsip-prinsip itu dengan penegasan bahwa Dia-lah yang telah memberi karunia rezeki melalui alam yang serba potensial sehingga kesulitan pangan dapat teratasi (QS. al-Baqarah: 57, 58 dan 6061), karena itu hendaknya umat manusia hanya mengkonsumsi yang halal dan baik dan tidak mengikuti hawa nafsu (langkah setan) melainkan sesuai dengan kadar kebutuhan (QS al-Baqarah: 168). Ciri orang beriman adalah yang hanya melakukan konsumsi yang baik-baik dari karunia rezeki Allah disertai rasa syukur hanya kepada Allah atas nikmat-Nya. (QS. al-Baqaarah:172-173).

Mengadu kepada pengadilan untuk memenangkan perkara dengan cara menyogok hakim adalah perbuatan yang sangat dilarang. Karena itu dalam dalam hubungan kerja sama untuk konsumsi harus berdasarkan azaz keadilan yaitu saling menguntungkan (QS. al-Baqarah: 188). Perilaku hubungan konsumsi juga harus jauh dari kedzaliman atau tidak mengandung kedzaliman. (QS. an-Nisa, 4:10)

Demikian pula dalam konsumsi dan pengembangan harta benda tidak boleh mengandung kebatilan melainkan harus saling menguntungkan (QS an-Nisa: 29). Di antata contoh-contoh makanan yang mengandung kebatilan adalah apa-apa yang diharamkan Allah (QS. al-Maidah: 3).

Untuk merealisasikan perilaku konsumsi yang baik demikian, maka masyarakat muslim harus berkomitmen dan teguh di dalamnya (QS. al-Maidah: 88) dan tidak meniru pada perilaku tradisi masyarakat lain. Perilaku konsumsi muslim harus jauh dari sifat-sifat loba, tamak, suka menimbun harta, mengambil harta orang lain dengan cara-cara yang batil hingga manipulasi ajaran agama untuk kepentingan harta benda (QS. at-Taubah: 34). 


\section{DAFTAR PUSTAKA}

Al-Banna, Hasan. 1997. Risalab Pergerakan Ikbwanul Muslimin. Jakarta: Intermedia. Anom Surya Putra. "Man ista'jara ajran fal yu’alimhu ajrahu. mnvu.nu.online. Accessed 14 Januari 2008.

Baqi, Muhammad Fu'ad Abdul. 1988. Mu'jam al-Mufabrasy lialfadzi Qur'an. Qahitah: Dar al-hadis.

Karim, Adiwarman Azwat. 2002. Ekonomi Islam: Suatu Kajian Ekonomi Makro. Jakarta: The International Institute of Islamic Thought Indonesia (IIIT Indonesia)

Khan, Muhammad Akram. 1997. "The Role of Government in the Economy," dalam The American Journal of Islamic Social Sciences, Vol. 14, No. 2

Lukman Fauroni. 2006. Etika Bisnis dalam al-Qur'an. Yogyakarta: Pustaka Pesantren. Munawir, Ahmad Warson. 1883. Kamus al-Munawnir. Yogyakarta: Pondok Pesantren Krapyak.

Qardhawi,Yusuf. 1995. "Peran Nilai dan Moral dalam Perekonomian Islam." Jakarta: Rabbani Press.

Salim, Abd Muin. 1994. Konsepsi Kekuasaan Politk dalam al-Qur'an, Jakarta: LSIK

Shihab, M Quraisy. 2003. Tafsir Al-Misbab Pesan, Kesan dan Keserasian al-Qur'an. Jakarta: Lentera Hati.

Sukirno, Sadono. 1997. Pengantar Teori Mikroekonomi. Jakarta: Rajawali Press Jakarta Umar Burhan. 2006. Konsep Dasar Teori Ekonomi Mikro. Surabaya: BPFE UNIBRAW. 